\title{
Effect of Temperature and Duration of Pulsing with Silver Thiosulphate (STS) on the Peroxidative Changes during Vase Life Period of Cut Rose cv. 'First Red'
}

\author{
V. Vijaya Bhaskar* and P. Venkata Rao \\ Department of Horticulture, College of Agriculture, Acharya N. G. Ranga Agricultural \\ University, Rajendranagar, Hyderabad-500 030, Andhra Pradesh, India
}

*Corresponding author

A B S T R A C T

Keywords

Rose, Catalase,

Peroxidase, STS,

Temperature

Article Info

Accepted:

24 January 2018

Available Online:

10 February 2018
The present investigation dealt with the effect of temperature and duration of pulsing with silver thiosulphate (STS) on the peroxidative changes of cut rose petals during vase life period. From the investigation it was proved that flowers pulsed with $0.4 \mathrm{mM}$ STS at $10^{\circ} \mathrm{C}$ for a short period of 8 hours significantly decreased the catalase and peroxidase activities thereby extending the shelf life of cut roses. The enhanced longevity of cut roses was due to suppressing the formation of peroxides and free radicals in the plant tissue. A delay in the formation of peroxides and free radicals ultimately led to membrane integrity thereby increased vase life of cut roses.

\section{Introduction}

Rose has been considered as the strongest competent among the cut flowers both in the domestic as well as international trade. Its demand has increased greatly in the semiurban and urban areas all over the world. However, low keeping quality of cut roses badly affected the growers as well as the traders in the recent past in India. In the commercial use of cut flowers, it is usually the life span of the petals which determine the effective life of the flower, but petals are generally short lived owing to their tenderness and delicate nature leading to rapid deterioration in quality and ultimately shorten the vase life. Generally, cut flowers carry-on all life processes at the expense of stored reserve food in the form of carbohydrates, proteins and fats, limiting their longevity and pose problems in handling and marketing. Since water relations play an important role in the postharvest physiology and biochemistry of cut flowers, the continuity of water to the cut flower should be ensured. Apart from these, treatment of cut flowers with chemicals can reduce the effect of ethylene and enzymatic changes, which ultimately reduces the senescence of petals there by enhance the cut flower life. Keeping these things in view, 
the present investigation aimed towards discerning the peroxidative changes leading to senescence of cut roses by pulsing with STS for different durations at different temperatures.

\section{Materials and Methods}

Flowers of rose (Rosa hybrida L.) cv. 'First Red' obtained from a commercial green-house located near Hyderabad, $12 \mathrm{~km}$ away from the ANGRAU campus were used for the experimentation. Rose flower stalks/shoots of about $50 \mathrm{~cm}$ in length were harvested when the first petal was unfurling and ready to open. The flower stems were harvested in the morning to avoid excessive heat and immediately the flowers were held in deionized water and handled uniformly before treatment. The flowers were brought to the laboratory within two hours after harvest. Flower stems were trimmed under water to 45 $\mathrm{cm}$ and all the leaves except 2 to 3 compound leaves below the flower bud, were removed to avoid contact with the solution (Buys, 1969).

The flower stalks were placed in the preconditioning solutions for 8,16 and 24 hours pulsing at $10^{\circ} \mathrm{C}$ and room temperature $\left(22+2^{\circ} \mathrm{C}\right)$. The flowers were returned back to room temperature, in case of $10^{\circ} \mathrm{C}$ pulsing, after completion of a pre-set period of duration and placed in distilled water for the rest of the experiment to evaluate their vase life. The flowers were continuously held in distilled water till the end of vase life. The solutions were prepared with distilled water and only freshly prepared solutions were used in the experimentation. Each conical flask held 5 flowers and considered a replication. The individual flower stems were placed randomly in the $500 \mathrm{ml}$ conical flask containing $300 \mathrm{ml}$ of distilled water. The narrow mouth of the conical flask was sealed with non-absorbent cotton, which effectively prevented the evaporational loss of water.
The experiment was conducted during the year 2001 and the experimental flowers were held in the laboratory at about $22+2^{\circ} \mathrm{C} \mathrm{RT}, 50 \%$ to $70 \% \mathrm{RH}$ and $0.38 \mathrm{Wm}^{-2}$ cool-white fluorescent lights on a 12 hours photoperiod basis. The pulsing treatments were $\mathrm{T}_{1: 0.4 \mathrm{mM}}$ STS $-10^{\circ} \mathrm{C}-8 \mathrm{~h}, \mathrm{~T}_{2:}: 0.4 \mathrm{mM}$ STS $-10^{\circ} \mathrm{C}-$ $16 \mathrm{~h}, \mathrm{~T}_{3}: 0.4 \mathrm{mM} \mathrm{STS}-10^{\circ} \mathrm{C}-24 \mathrm{~h}, \mathrm{~T}_{4}: 0.4$ $\mathrm{mM} \mathrm{STS}-\mathrm{RT}-8 \mathrm{~h}, \mathrm{~T}_{5}: 0.4 \mathrm{mM}$ STS $-\mathrm{RT}-$ $16 \mathrm{~h}, \mathrm{~T}_{6}: 0.4 \mathrm{mM}$ STS $-\mathrm{RT}-24 \mathrm{~h}, \mathrm{~T}_{7}: 0.8 \mathrm{mM}$ STS $-10^{\circ} \mathrm{C}-8 \mathrm{~h}, \mathrm{~T}_{8}: 0.8 \mathrm{mM}$ STS $-10^{\circ} \mathrm{C}-$ 16h, $\mathrm{T}_{9}: 0.8 \mathrm{mM}$ STS $-10^{\circ} \mathrm{C}-24 \mathrm{~h}, \mathrm{~T}_{10}: 0.8$ mM STS - RT - 8h, T $11: 0.8 \mathrm{mM}$ STS - RT $16 \mathrm{~h}, \mathrm{~T}_{12}: 0.8 \mathrm{mM}$ STS $-\mathrm{RT}-24 \mathrm{~h}$. All the treatments replicated thrice in a completely randomized design with factorial concept. The observations recorded by adopting the following methods.

\section{Extraction of sample for the assay of enzyme activity}

One gram of fresh rose petal tissue was homogenized in a pre-chilled mortar and pestle with $0.1 \mathrm{M}$ phosphate buffer $(\mathrm{pH}$ 7.0) and 0.1 per cent polyvinyl pyrrollydone (PVP), and centrifuged at $27,000 \mathrm{Xg}$ for 20 minutes. The clear supernatant enzyme extract was used for the assays of catalase and peroxidase activities. Enzyme extraction was carried out at 0 to $4^{\circ} \mathrm{C}$, whereas, enzyme activity estimation was done at room temperature (i.e., $27^{\circ} \mathrm{C}$ ).

\section{Assay of catalase (EC 1.11.1.6) activity}

Catalase activity was measured spectrophotometrically by direct measurement of the decrease of light absorption in the region 230 to $250 \mathrm{~nm}$ caused by the decomposition of hydrogen peroxide $\left(\mathrm{H}_{2} \mathrm{O}_{2}\right)$ by catalase (Chance and Maehly, 1955). Fifty micro litres of enzyme sample was added to $2.5 \mathrm{ml}$ of $0.1 \mathrm{M}$ phosphate buffer ( $\mathrm{pH} 7.0)$ containing 0.5 $\mathrm{ml}$ of $0.5 \% \quad \mathrm{H}_{2} \mathrm{O}_{2}$ and the change in absorbance at $230 \mathrm{~nm}$ was recorded with 
spectrophotometer (Hitachi, U-2000 UV-Vis spectro-photometer). The reference cuvette contained an identical homogenate sample in $2.5 \mathrm{ml}$ of $0.1 \mathrm{M}$ phosphate buffer ( $\mathrm{pH} 7.0$ ) without $\mathrm{H}_{2} \mathrm{O}_{2}$. The enzyme activity was expressed as units/gram fresh weight of tissue ( 1 unit $=1 \mu$ mole/second $)$.

\section{Assay of peroxidase (EC 1.11.1.7) activity}

The traditional test for peroxidase activity was the formation of purpurogallin from pyrogallol (Chance and Maehly, 1955). For the assay of peroxidase, $3.5 \mathrm{ml}$ of the assay mixture contained $2.8 \mathrm{ml}$ of pyrogallol made with phosphate buffer ( $\mathrm{pH} 7.0$ ), $0.5 \mathrm{ml}$ of $1 \% \mathrm{H}_{2} \mathrm{O}_{2}$ and 200 microlitres of enzyme. The rate change in absorbance at $430 \mathrm{~nm}$ was measured using a Hitachi U-2000 UV-Vis spectro photometer. The reference cuvette contained an identical homogenate sample without enzyme. The enzyme activity was expressed as units/gram fresh weight of tissue ( 1 unit $=1$ $\mu$ mole / minute).

The data were subjected to statistical analysis as per the procedure outlined by Panse and Sukhatme (1978). The results were analysed using analysis of variance (ANOVA) and Ftest analysis. Least significant difference was used for comparison between the treatments.

\section{Results and Discussion}

\section{Catalase activity}

The changes in CAT activity during vase life period of cut rose cv. First Red, pulsed with STS at different temperatures and pulsing durations are presented in table 1. There were significant differences in the CAT activity between the concentrations of pulsing with STS during vase life period, except on day 1 and 9. On day 3, 5 and 7, flowers pulsed with higher concentration of STS recorded highest CAT activity over lower concentration, whereas, on day 11, pulsing with lower concentration of STS recorded highest (39.9) CAT activity over higher concentration (39.0), indicating that the lower concentration of STS delayed the onset of senescence in cut roses. There were no significant differences in the CAT activity between the temperatures of pulsing with STS, except on day 7 and 9, where flowers pulsed at RT recorded highest CAT activity over $10^{\circ} \mathrm{C}$, showing the early onset of senescence in the floral tissue.

There were no significant differences in the CAT activity among the durations of pulsing with STS, except on day 1 and 3. Flowers pulsed for $24 \mathrm{~h}$ recorded highest CAT activity, whereas, 8h pulsing recorded lowest CAT activity. Lower the CAT activity means lower the peroxidation of lipids.

The interaction effect on CAT activity between concentrations and temperatures was not significant during the vase life period, except on day 3. Flowers pulsed with higher concentration of STS at RT recorded highest (38.8) CAT activity, whereas, lower concentration of STS, irrespective of temperature recorded lower CAT activity.

The interaction effect on CAT activity between concentrations and durations was not significant during the vase life period, except on day 3 . Flowers pulsed for $16 \mathrm{~h}$ and $24 \mathrm{~h}$ with higher concentration of STS recorded higher CAT activity, however, $8 \mathrm{~h}$ pulsing with higher concentration recorded lowest (37.8) CAT activity, which was at par with $8 \mathrm{~h}$ and $16 \mathrm{~h}$ pulsing of STS lower concentrations. The interaction effect on CAT activity between temperatures and durations was not significant throughout the vase life period.

The interaction effect on CAT activity among concentrations, temperatures and durations was also not significant throughout the vase life period. 
Table.1 Effect of temperature and duration of pulsing with STS on catalase activity (units/gfw) during vase life period of cut rose cv. First Red

\begin{tabular}{|c|c|c|c|c|c|c|}
\hline \multirow[t]{2}{*}{ Source of Variation } & \multicolumn{6}{|l|}{ Days } \\
\hline & 1 & 3 & 5 & 7 & 9 & 11 \\
\hline \multicolumn{7}{|l|}{ Concentrations } \\
\hline $\mathrm{C}_{1}(\mathrm{STS} 0.4 \mathrm{mM})$ & 38.9 & 38.2 & 38.5 & 38.8 & 39.5 & 39.9 \\
\hline $\mathrm{C}_{2}(\mathrm{STS} 0.8 \mathrm{mM})$ & 38.6 & 38.6 & 39.2 & 39.6 & 39.9 & 39.0 \\
\hline F-test & NS & $* *$ & $* *$ & $* *$ & NS & $* *$ \\
\hline C.D at $5 \%$ & - & 0.07 & 0.09 & 0.12 & - & 0.15 \\
\hline \multicolumn{7}{|l|}{ Temperatures } \\
\hline $\mathrm{T}_{1}\left(10^{\circ} \mathrm{C}\right)$ & 38.7 & 38.3 & 38.7 & 38.9 & 39.3 & 39.6 \\
\hline $\mathrm{T}_{2}(\mathrm{RT})$ & 38.8 & 38.4 & 39.0 & 39.4 & 40.1 & 39.3 \\
\hline F-test & NS & NS & NS & $*$ & $*$ & NS \\
\hline C.D at $5 \%$ & - & - & - & 0.12 & 0.14 & - \\
\hline \multicolumn{7}{|l|}{ Durations } \\
\hline $\mathrm{D}_{1}(8 \mathrm{hrs})$ & 38.2 & 37.9 & 38.8 & 38.9 & 39.3 & 39.5 \\
\hline $\mathrm{D}_{2}(16 \mathrm{hrs})$ & 38.8 & 38.4 & 38.7 & 39.3 & 39.7 & 39.1 \\
\hline $\mathrm{D}_{3}(24 \mathrm{hrs})$ & 39.2 & 38.8 & 39.1 & 39.3 & 40.1 & 39.7 \\
\hline F-test & $* *$ & $* *$ & NS & NS & NS & NS \\
\hline C.D at $5 \%$ & 0.14 & 0.01 & - & - & - & - \\
\hline \multicolumn{7}{|c|}{ Concentrations $X$ Temperatures } \\
\hline $\mathrm{C}_{1} \mathrm{~T}_{1}$ & 38.9 & 38.2 & 38.4 & 38.4 & 39.2 & 39.9 \\
\hline $\mathrm{C}_{1} \mathrm{~T}_{2}$ & 38.9 & 38.1 & 38.6 & 39.1 & 39.8 & 39.9 \\
\hline $\mathrm{C}_{2} \mathrm{~T}_{1}$ & 38.4 & 38.3 & 39.0 & 39.4 & 39.4 & 39.2 \\
\hline $\mathrm{C}_{2} \mathrm{~T}_{2}$ & 38.7 & 38.8 & 39.4 & 39.8 & 40.4 & 38.8 \\
\hline F-test & NS & $*$ & NS & NS & NS & NS \\
\hline C.D at $5 \%$ & - & 0.13 & - & - & - & - \\
\hline \multicolumn{7}{|c|}{ Concentrations $X$ Durations } \\
\hline $\mathrm{C}_{1} \mathrm{D}_{1}$ & 38.3 & 38.0 & 38.5 & 38.2 & 39.2 & 39.5 \\
\hline $\mathrm{C}_{1} \mathrm{D}_{2}$ & 39.0 & 38.0 & 38.3 & 39.0 & 39.7 & 39.8 \\
\hline $\mathrm{C}_{1} \mathrm{D}_{3}$ & 39.3 & 38.5 & 38.7 & 39.2 & 39.7 & 40.3 \\
\hline $\mathrm{C}_{2} \mathrm{D}_{1}$ & 38.0 & 37.8 & 39.2 & 39.7 & 39.5 & 39.5 \\
\hline $\mathrm{C}_{2} \mathrm{D}_{2}$ & 38.7 & 38.8 & 39.0 & 39.7 & 39.8 & 38.3 \\
\hline $\mathrm{C}_{2} \mathrm{D}_{3}$ & 39.0 & 39.0 & 39.5 & 39.5 & 40.5 & 39.2 \\
\hline F-test & NS & $*$ & NS & NS & NS & NS \\
\hline C.D at $5 \%$ & - & 0.20 & - & - & - & - \\
\hline \multicolumn{7}{|c|}{ Temperatures X Durations } \\
\hline $\mathrm{T}_{1} \mathrm{D}_{1}$ & 38.2 & 37.8 & 38.7 & 39.0 & 39.2 & 39.8 \\
\hline $\mathrm{T}_{1} \mathrm{D}_{2}$ & 38.7 & 38.3 & 38.5 & 39.2 & 39.3 & 39.2 \\
\hline$T_{1} D_{3}$ & 39.2 & 38.7 & 39.0 & 38.7 & 39.5 & 39.7 \\
\hline $\mathrm{T}_{2} \mathrm{D}_{1}$ & 38.2 & 38.0 & 39.0 & 38.8 & 39.5 & 39.2 \\
\hline $\mathrm{T}_{2} \mathrm{D}_{2}$ & 39.0 & 38.5 & 38.8 & 39.5 & 40.2 & 39.0 \\
\hline$T_{2} D_{3}$ & 39.2 & 38.8 & 39.2 & 40.0 & 40.7 & 39.8 \\
\hline F-test & NS & NS & NS & NS & NS & NS \\
\hline C.D at $5 \%$ & - & - & - & - & - & - \\
\hline \multicolumn{7}{|c|}{ Concentrations X Temperatures X Durations } \\
\hline $\mathrm{C}_{1} \mathrm{~T}_{1} \mathrm{D}_{1}$ & 38.3 & 38.0 & 38.3 & 38.0 & 39.0 & 40.0 \\
\hline $\mathrm{C}_{1} \mathrm{~T}_{1} \mathrm{D}_{2}$ & 38.7 & 38.0 & 38.3 & 38.7 & 39.0 & 39.7 \\
\hline $\mathrm{C}_{1} \mathrm{~T}_{1} \mathrm{D}_{3}$ & 39.7 & 38.7 & 38.7 & 38.7 & 39.7 & 40.0 \\
\hline $\mathrm{C}_{1} \mathrm{~T}_{2} \mathrm{D}_{1}$ & 38.3 & 38.0 & 38.7 & 38.3 & 39.3 & 39.0 \\
\hline $\mathrm{C}_{1} \mathrm{~T}_{2} \mathrm{D}_{2}$ & 39.3 & 38.0 & 38.3 & 39.3 & 40.3 & 40.0 \\
\hline $\mathrm{C}_{1} \mathrm{~T}_{2} \mathrm{D}_{3}$ & 39.0 & 38.3 & 38.7 & 39.7 & 39.7 & 40.7 \\
\hline $\mathrm{C}_{2} \mathrm{~T}_{1} \mathrm{D}_{1}$ & 38.0 & 37.7 & 39.0 & 40.0 & 39.3 & 39.7 \\
\hline $\mathrm{C}_{2} \mathrm{~T}_{1} \mathrm{D}_{2}$ & 38.7 & 38.7 & 38.7 & 39.7 & 39.7 & 38.7 \\
\hline $\mathrm{C}_{2} \mathrm{~T}_{1} \mathrm{D}_{3}$ & 38.7 & 38.7 & 39.3 & 38.7 & 39.3 & 39.3 \\
\hline $\mathrm{C}_{2} \mathrm{~T}_{2} \mathrm{D}_{1}$ & 38.0 & 38.0 & 39.3 & 39.3 & 39.7 & 39.3 \\
\hline $\mathrm{C}_{2} \mathrm{~T}_{2} \mathrm{D}_{2}$ & 38.7 & 39.0 & 39.3 & 39.7 & 40.0 & 38.0 \\
\hline $\mathrm{C}_{2} \mathrm{~T}_{2} \mathrm{D}_{3}$ & 39.3 & 39.3 & 39.7 & 40.3 & 41.7 & 39.0 \\
\hline F-test & NS & NS & NS & NS & NS & NS \\
\hline C.D at $5 \%$ & - & - & - & - & - & - \\
\hline
\end{tabular}

C: Concentration T: Temperature D: Duration RT: Room Temperature NS: Not significant 
Table.2 Effect of temperature and duration of pulsing with STS on peroxidase activity (units/gfw) during vase life period of cut rose cv. First Red

\begin{tabular}{|c|c|c|c|c|c|c|c|}
\hline \multirow[t]{2}{*}{ Source of Variation } & \multicolumn{6}{|l|}{ Days } & \multirow{2}{*}{$\begin{array}{c}\text { Vase life } \\
\text { (Days) }\end{array}$} \\
\hline & 1 & 3 & 5 & 7 & 9 & 11 & \\
\hline \multicolumn{8}{|l|}{ Concentrations } \\
\hline $\mathrm{C}_{1}(\mathrm{STS} 0.4 \mathrm{mM})$ & 32.0 & 34.0 & 41.0 & 45.0 & 46.0 & 45.0 & 10.511 \\
\hline $\mathrm{C}_{2}(\mathrm{STS} 0.8 \mathrm{mM})$ & 38.0 & 42.0 & 43.0 & 44.0 & 45.0 & 47.0 & 9.683 \\
\hline F-test & $* *$ & $* *$ & NS & NS & NS & NS & $* *$ \\
\hline C.D at $5 \%$ & 0.6 & 0.5 & - & - & - & - & 0.0942 \\
\hline \multicolumn{8}{|l|}{ Temperatures } \\
\hline $\mathrm{T}_{1}\left(10^{\circ} \mathrm{C}\right)$ & 28.0 & 36.0 & 38.0 & 41.0 & 44.0 & 46.0 & 10.478 \\
\hline $\mathrm{T}_{2}(\mathrm{RT})$ & 41.0 & 40.0 & 46.0 & 48.0 & 48.0 & 47.0 & 9.717 \\
\hline F-test & $* *$ & $* *$ & $* *$ & $* *$ & $* *$ & NS & $* *$ \\
\hline C.D at $5 \%$ & 0.6 & 0.5 & 0.5 & 0.5 & 0.6 & -- & 0.0942 \\
\hline \multicolumn{8}{|l|}{ Durations } \\
\hline $\mathrm{D}_{1}(8 \mathrm{hrs})$ & 31.0 & 35.0 & 43.0 & 40.0 & 46.0 & 55.0 & 11.100 \\
\hline $\mathrm{D}_{2}(16 \mathrm{hrs})$ & 37.0 & 40.0 & 41.0 & 43.0 & 53.0 & 42.0 & 9.925 \\
\hline $\mathrm{D}_{3}(24 \mathrm{hrs})$ & 36.0 & 38.0 & 42.0 & 52.0 & 38.0 & 41.0 & 9.267 \\
\hline F-test & $* *$ & $* *$ & NS & $* *$ & $* *$ & $* *$ & $* *$ \\
\hline C.D at $5 \%$ & 0.8 & 0.8 & -- & 0.7 & 0.9 & 0.14 & 0.1413 \\
\hline \multicolumn{8}{|c|}{ Concentrations $X$ Temperatures } \\
\hline $\mathrm{C}_{1} \mathrm{~T}_{1}$ & 24.0 & 31.0 & 37.0 & 43.0 & 47.0 & 47.0 & 11.000 \\
\hline $\mathrm{C}_{1} \mathrm{~T}_{2}$ & 39.0 & 37.0 & 45.0 & 47.0 & 45.0 & 43.0 & 10.022 \\
\hline $\mathrm{C}_{2} \mathrm{~T}_{1}$ & 32.0 & 41.0 & 38.0 & 40.0 & 40.0 & 45.0 & 9.956 \\
\hline $\mathrm{C}_{2} \mathrm{~T}_{2}$ & 43.0 & 43.0 & 47.0 & 49.0 & 50.0 & 50.0 & 9.411 \\
\hline F-test & $*$ & NS & NS & $* *$ & $* *$ & $*$ & NS \\
\hline C.D at $5 \%$ & 1.1 & - & - & 0.9 & 1.2 & 1.9 & - \\
\hline \multicolumn{8}{|c|}{ Concentrations X Durations } \\
\hline $\mathrm{C}_{1} \mathrm{D}_{1}$ & 31.0 & 29.0 & 41.0 & 40.0 & 52.0 & 57.0 & 11.533 \\
\hline $\mathrm{C}_{1} \mathrm{D}_{2}$ & 35.0 & 38.0 & 39.0 & 40.0 & 50.0 & 37.0 & 10.467 \\
\hline $\mathrm{C}_{1} \mathrm{D}_{3}$ & 30.0 & 34.0 & 44.0 & 56.0 & 37.0 & 41.0 & 9.533 \\
\hline $\mathrm{C}_{2} \mathrm{D}_{1}$ & 31.0 & 41.0 & 46.0 & 41.0 & 40.0 & 53.0 & 10.667 \\
\hline $\mathrm{C}_{2} \mathrm{D}_{2}$ & 39.0 & 42.0 & 43.0 & 45.0 & 56.0 & 48.0 & 9.383 \\
\hline $\mathrm{C}_{2} \mathrm{D}_{3}$ & 43.0 & 43.0 & 40.0 & 47.0 & 40.0 & 42.0 & 9.000 \\
\hline F-test & $* *$ & $*$ & $* *$ & $* *$ & $* *$ & $*$ & NS \\
\hline C.D at $5 \%$ & 1.7 & 1.5 & 1.4 & 1.4 & 1.7 & 2.8 & -- \\
\hline \multicolumn{8}{|c|}{ Temperatures X Durations } \\
\hline $\mathrm{T}_{1} \mathrm{D}_{1}$ & 21.0 & 32.0 & 36.0 & 37.0 & 44.0 & 52.0 & 11.233 \\
\hline $\mathrm{T}_{1} \mathrm{D}_{2}$ & 30.0 & 36.0 & 37.0 & 42.0 & 51.0 & 48.0 & 10.600 \\
\hline $\mathrm{T}_{1} \mathrm{D}_{3}$ & 33.0 & 40.0 & 41.0 & 46.0 & 35.0 & 38.0 & 9.600 \\
\hline $\mathrm{T}_{2} \mathrm{D}_{1}$ & 40.0 & 38.0 & 51.0 & 44.0 & 47.0 & 58.0 & 10.967 \\
\hline $\mathrm{T}_{2} \mathrm{D}_{2}$ & 44.0 & 45.0 & 45.0 & 43.0 & 55.0 & 37.0 & 9.250 \\
\hline $\mathrm{T}_{2} \mathrm{D}_{3}$ & 39.0 & 37.0 & 42.0 & 58.0 & 41.0 & 45.0 & 8.933 \\
\hline F-test & $* *$ & $* *$ & $* *$ & $* *$ & NS & $* *$ & NS \\
\hline C.D at $5 \%$ & 1.7 & 1.5 & 1.4 & 1.4 & -- & 2.8 & -- \\
\hline \multicolumn{8}{|c|}{ Concentrations X Temperatures X Durations } \\
\hline $\mathrm{C}_{1} \mathrm{~T}_{1} \mathrm{D}_{1}$ & 16.0 & 27.0 & 35.0 & 36.0 & 51.0 & 60.0 & 11.600 \\
\hline $\mathrm{C}_{1} \mathrm{~T}_{1} \mathrm{D}_{2}$ & 29.0 & 32.0 & 35.0 & 37.0 & 54.0 & 41.0 & 11.400 \\
\hline $\mathrm{C}_{1} \mathrm{~T}_{1} \mathrm{D}_{3}$ & 28.0 & 33.0 & 42.0 & 56.0 & 36.0 & 40.0 & 10.000 \\
\hline $\mathrm{C}_{1} \mathrm{~T}_{2} \mathrm{D}_{1}$ & 46.0 & 31.0 & 46.0 & 43.0 & 52.0 & 54.0 & 11.467 \\
\hline $\mathrm{C}_{1} \mathrm{~T}_{2} \mathrm{D}_{2}$ & 41.0 & 44.0 & 43.0 & 43.0 & 47.0 & 34.0 & 9.533 \\
\hline $\mathrm{C}_{1} \mathrm{~T}_{2} \mathrm{D}_{3}$ & 31.0 & 35.0 & 45.0 & 56.0 & 37.0 & 41.0 & 9.067 \\
\hline $\mathrm{C}_{2} \mathrm{~T}_{1} \mathrm{D}_{1}$ & 27.0 & 37.0 & 36.0 & 37.0 & 37.0 & 43.0 & 10.867 \\
\hline $\mathrm{C}_{2} \mathrm{~T}_{1} \mathrm{D}_{2}$ & 32.0 & 39.0 & 38.0 & 47.0 & 49.0 & 55.0 & 9.800 \\
\hline $\mathrm{C}_{2} \mathrm{~T}_{1} \mathrm{D}_{3}$ & 38.0 & 46.0 & 39.0 & 35.0 & 34.0 & 36.0 & 9.200 \\
\hline $\mathrm{C}_{2} \mathrm{~T}_{2} \mathrm{D}_{1}$ & 34.0 & 45.0 & 56.0 & 44.0 & 42.0 & 62.0 & 10.467 \\
\hline $\mathrm{C}_{2} \mathrm{~T}_{2} \mathrm{D}_{2}$ & 46.0 & 45.0 & 47.0 & 43.0 & 63.0 & 40.0 & 8.967 \\
\hline $\mathrm{C}_{2} \mathrm{~T}_{2} \mathrm{D}_{3}$ & 48.0 & 39.0 & 40.0 & 59.0 & 45.0 & 48.0 & 8.800 \\
\hline F-test & $* *$ & $*$ & NS & $* *$ & $*$ & $*$ & NS \\
\hline C.D at $5 \%$ & 3.4 & 3.0 & -- & 2.7 & 3.5 & 5.7 & -- \\
\hline
\end{tabular}

C: Concentration T: Temperature D: Duration RT: Room Temperature NS: Not significant 
The data obtained from the present investigation suggest that during vase life period of cut rose, the increase in concentration, temperature and duration of pulsing would have increased the peroxidative products and free radicals which react with cellular constituents thereby promoting the senescence.

\section{Peroxidase activity}

The changes in POD activity during vase life period of cut rose cv. First Red pulsed with STS at different temperatures and pulsing durations are presented in table 2. Except on day 1 and 3 , there were no significant differences in the POD activity between the concentrations of pulsing with STS during vase life period. On day 1 and 3, flowers pulsed with higher concentration of STS recorded highest POD activity over the lower concentration. There were significant differences in the POD activity between the temperatures of pulsing with STS during vase life period, except on day 11. Flowers pulsed at RT recorded higher POD activity throughout the vase life period over $10^{\circ} \mathrm{C}$.

There were significant differences in the POD activity among the durations of pulsing with STS during vase life period, except on day 5. The flowers pulsed for $8 \mathrm{~h}$ duration recorded significantly lower POD activities over $16 \mathrm{~h}$ and $24 \mathrm{~h}$ duration of pulsing. The flowers pulsed for $16 \mathrm{~h}$ and $24 \mathrm{~h}$ duration recorded higher POD activities. In all the three durations of pulsing the POD activity gradually increased with the passing of time and reached to the peak at senescence. Since then the POD activity gradually decreased.

The interaction effect on POD activity between concentrations and temperatures was significant during the vase life period, except on day 3 and 5. Flowers pulsed with higher concentration of STS at RT recorded significantly higher POD activity, whereas, flowers pulsed with lower concentration of STS at $10^{\circ} \mathrm{C}$ recorded lower and moderate POD activity throughout the vase life period when compared with other interactions.

The interaction effect on POD activity between concentrations and durations was significant during the vase life period. Flowers pulsed with STS for $8 \mathrm{~h}$ duration recorded significantly lower POD activity. An increase in the duration of pulsing has recorded higher POD activity irrespective of the concentration. However, based on the visible quality parameters, flowers pulsed with lower concentration for $8 \mathrm{~h}$ duration was found good.

The interaction effect on POD activity between the temperatures and durations was also significant during the vase life period, except on day 9. Flowers pulsed for $8 \mathrm{~h}$ duration at $10^{\circ} \mathrm{C}$ recorded significantly lower POD activity till to the onset of senescence, whereas, flowers pulsed at RT recorded significantly higher POD activity right from the beginning, indicating early senescence.

The interaction effect on POD activity among concentrations, temperatures and durations was significant during vase life period, except on day 5. Flowers pulsed with lower concentration of STS at $10^{\circ} \mathrm{C}$ for $8 \mathrm{~h}$ duration recorded significantly lower POD activity throughout the vase life period, except during the senescing stage. Flowers pulsed with higher concentration of STS at RT, irrespective of the duration of pulsing have recorded significantly higher POD activity.

Based on the above observations, flowers pulsed with lower concentration of STS at $10^{\circ} \mathrm{C}$ for $8 \mathrm{~h}$ pulsing effectively controlled the POD activity and always kept at lower levels till to the onset of senescence. These results suggest that concentration of chemical, 
temperature and duration of pulsing had major impact on the formation of peroxides and free radicals.

\section{References}

Buys, C. 1969. Leaves influence the vase life of cut flowers. Zierpflanzenbau 9: 639640.
Chance, B. and Maehly, A. C. 1955. Assay of catalases and peroxidases. Methods in Enzymology 2: 764-813.

Panse, V.G. and Sukhatme, P.V. 1978. Statistical methods for agricultural workers. Indian Council of Agricultural Research Publications, New Delhi.

\section{How to cite this article:}

Vijaya Bhaskar, V. and Venkata Rao, P. 2018. Effect of Temperature and Duration of Pulsing with Silver Thiosulphate (STS) on the Peroxidative Changes during Vase Life Period of Cut Rose cv. 'First Red'. Int.J.Curr.Microbiol.App.Sci. 7(02): 2515-2521. doi: https://doi.org/10.20546/ijcmas.2018.702.306 